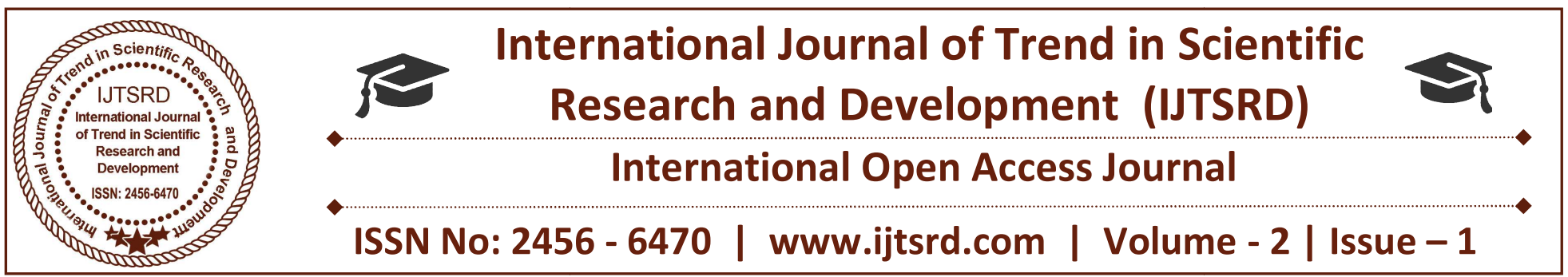

\title{
Assessment of the Engineering Properties and Suitability of some Tropical Soils as Backfill Materials
}

\author{
Johnbosco C. Egbueri \\ Department of Geology, Faculty of \\ Physical Sciences, University of \\ Nigeria, Nsukka
}

\author{
Ogbonnaya Igwe \\ Department of Geology, Faculty of \\ Physical Sciences, University of \\ Nigeria, Nsukka
}

\author{
Chidiebere H. Nnamani \\ Department of Geology and \\ Mining, Enugu State University of \\ Science and Technology, Enugu
}

\section{ABSTRACT}

Little to none has been known about some soils excavated for backfilling purposes in Anambra State, Southeastern Nigeria. Thus, this study, which involved literature reviews, field sampling, and integrated geotechnical analyses, presents an assessment of their engineering properties and suitability as backfill (foundation, embankment, subgrade, and base) materials. Eight soil samples (ABG, NIM, OZB, NKA, OKJ, ORK, ULI, and NBI) from eight borrow pits were studied. Grain-size analysis revealed that the eight soils are dominantly composed of medium-coarse grains. Laboratory USCS identified and grouped the soils into five - GP, SW, SP, SC and CL. Their permeability coefficients ranged from $4.22 \times 10^{-6}$ to $4.34 \times 10^{-4} \mathrm{~m} / \mathrm{sec}$, hence they are permeable. Compaction test revealed MDD range of $1.76-1.94 \mathrm{~g} / \mathrm{cm}^{3}$, OMC range of $13.29-17.10 \%$, and bulk density range of $1.68-1.90 \mathrm{~g} / \mathrm{cm}^{3}$. Their specific gravity ranged from 2.55-2.69. The soils have low natural moisture content, ranging from 1.61-8.00\%. Atterberg limits of the fines showed that they are nonplastic to low plastic materials, with the highest PI as $12 \%$ (for the CL soil). The soils have low cohesion $(0.66-6.72 \mathrm{kPa})$ but high frictional angle (32.54$36.47^{\circ}$ ), except for the CL soil which has $27.31 \mathrm{kPa}$ cohesion and $19.34^{\circ}$ friction angle. From the findings, it was deduced that, generally, these soils are good backfilling materials, though to varying degrees ( $\mathrm{SW}>\mathrm{GP}>\mathrm{SP}>\mathrm{SC}>\mathrm{CL}$ ), because of differences in their engineering properties. However, factors that could alter their good characteristics and suitability were discussed and recommendations given.
Keywords: tropical soils, geotechnical analysis, engineering properties, soil suitability, backfilling materials

\section{INTRODUCTION}

It is inarguable to say that soils are indomitable materials for most engineering constructions. Sand, gravel, and clay are examples of a wide range of materials that may be used in their raw state for backfilling purposes. Unconsolidated sediments provide the most immediate source of easily excavated gravel and sand used for backfilling projects [8].

However, [9, p. 23] stated that soils are naturally complex, multiphase materials consisting a matrix of an assortment of particles (solids), fluids, and gases. Each influences the behavior of the soil mass asa whole. They consist of discrete solid particles which are neither strongly bonded as in solids nor free as particles of fluids [3]. Consequently, the behavior of soil is somewhat intermediate between that of a solid and fluid. This then calls for a proper understanding of the engineering properties of a soil material, before it is used as backfilling aggregate. This study of soil properties (behaviors) and its suitability in construction project, such as backfilling, is within the circles of particulate (soil) mechanics and geological engineering $[3$, p. 2$]$.

Some workers [17][2][10][30] have done works assessing the suitability of several different materials 
for backfilling purposes. However, this work focuses on tropical soils. Tropical soils have a wide range index and engineering properties, which generally depend on several factors such as parent rock, mineralogy; degree of weathering, depth, rainfall intensity and temperature. All these factors are governed by geography and prevailing weather conditions [19]. Therefore, unless the composition of a soil mass is well understood, it will be difficult to estimate how it will behave under loads and how we can use it as a backfilling material [9, p. 23]. Such an understanding can be got through geotechnical inquiry.

Geotechnical investigation of soil is a fundamental step that reveals the physical and mechanical characteristics of the soil. It provides sufficient data to the engineers, planners, designers and contractors towards ensuring an economical projects for the type of soil to be used in terms of workability, strength, durability, and stability[25][13]. The properties of a soil, if well understood, give a better chance of generating adequate designs with correct specifications. These properties are the fundamental considerations that guide engineers into the production of sound designs and structures with integrity.

The failure of engineering structures founded on problematicgeologic units such as clay and unconsolidated sandy materials is common in some parts of Nigeria [27][14]. Many times, engineers, planners, designers and contractors give wrong recommendations and specifications because they are not at home with the properties and behaviors of the materials they use for certain projects. This is the major reason why many of the projects fail in no distant time. Many construction works have failed as a result of improper understanding and costly assumptions of the behaviors of the materials used in engineering constructions. Failures of structures resulting from problems like these are usually disastrous, costing many lives and properties. However, the impact of such disasters can be reduced by incorporating into building codes and other regulations appropriate measures, including adequate geotechnical analysis of construction materials (soils), so that structures will withstand potentially devastating structural failures [6].

In Anambra State, Nigeria, the rate at which new engineering construction projects which require backfilling are taking place is on a constant increase; andonly little or none has been known about the engineering properties of some soil materials excavated, for backfilling purposes, at various borrow pits in the State. Many engineers, both professional and nonprofessional, without adequate information about the soils' engineering properties and suitability, recommend, excavate, and or use them for different engineering projects. Therefore, there is a great need to understand the engineering characteristics of these soil materials excavated and used in various construction projects in Anambra State. In the light of this need, this work is targeted at (1) revealing the engineering properties of some tropical soils from eight different borrow pits in the State, (2) expressing their suitability as backfilling materials, and (3) revealing the external factors that can influence their properties and suitability as backfilling materials. This work, thus, provides the baseline assessment for the tropical soils excavated for backfilling purposes in the study area.

\section{LOCATION AND GEOLOGY OF THE EXCAVATION SITES}

Geographically, the excavation sites are located between Latitudes $5^{\circ} 45^{\mathrm{I}} \mathrm{N}$ to $6^{\circ} 10^{\mathrm{I}} \mathrm{N}$ and Longitudes $6^{\mathrm{o}} 45^{\mathrm{I}} \mathrm{E}$ to $7^{\mathrm{o}} 10^{\mathrm{I}} \mathrm{E}$. The study area is geologically situated within three formations - the Nanka, Ogwashi-Asaba, and Benin Formations (Fig. 1). The Nanka Formation is grouped into Anambra Basin while the Ogwashi-Asaba and Benin Formations are grouped into Niger-Delta Basin [12][22]. Some authors $[28][11][23][20]$ have submitted different ages for these three geologic formations. The Nanka Formation is dated Eocene, the Ogwashi-Asaba Formation is dated Oligocene-Miocene whereas the Benin is Oligocene. Therefore, chronologically, the Nanka Formation is the oldest (overlying Imo Formation/Shale) followed by the Ogwashi-Asaba. The Benin Formation is the youngest among the three geologic formations underlying the study area. A sedimentological review carried out showed that the Benin, Ogwashi-Asaba, and Nanka Formations have some common similarities. Reference [22] pointed out their properties, which appear to be common amongst them: (1) loose, poorly consolidated nature, (2) low clay contents, (3) pebbly natures which vary from one unit to the other, and (4) similar physical characters (except for pebbly nature) when compared to the famous friable Ajali Formation of the Anambra Basin. 


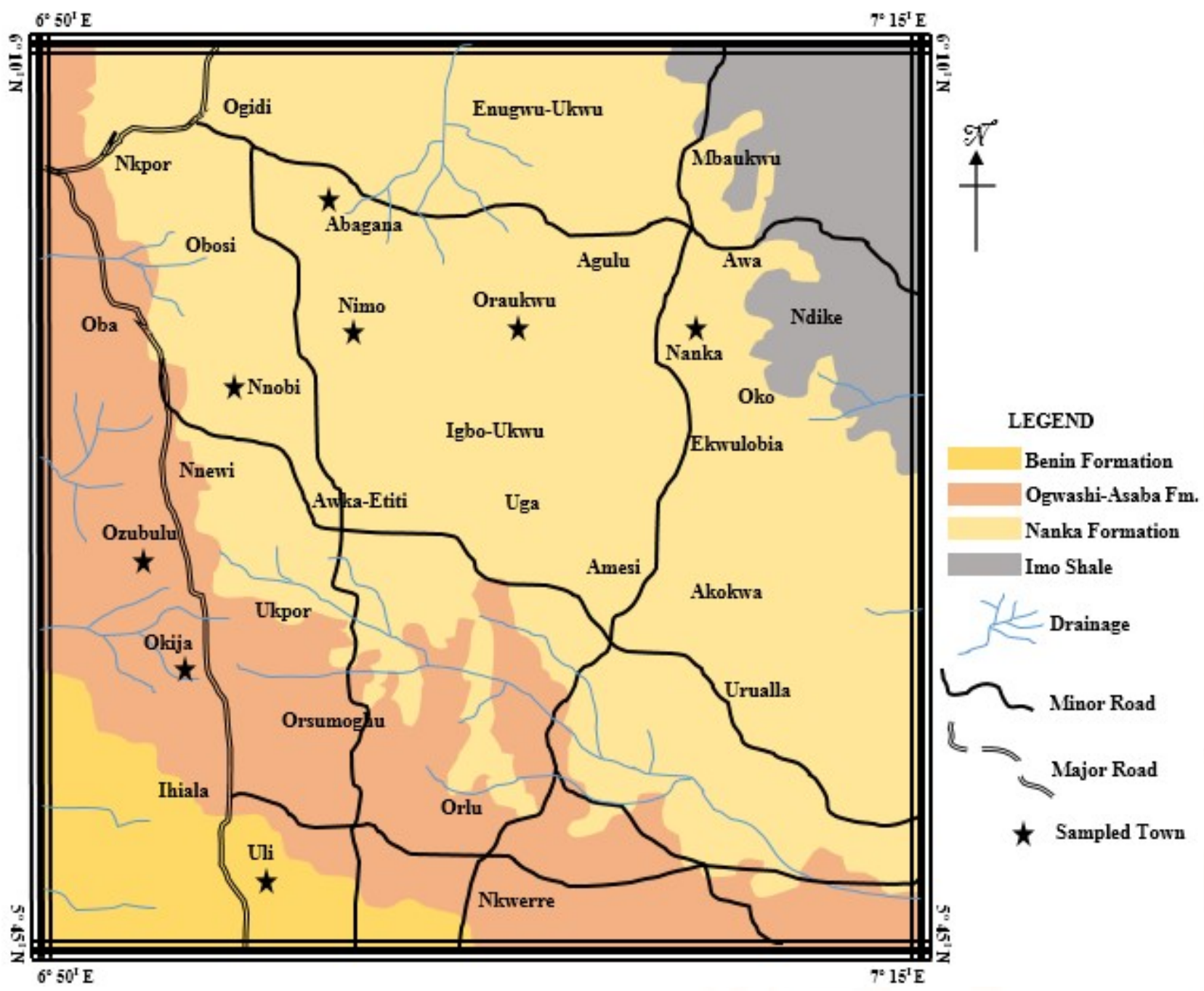

Fig 1: The geologic map of the study area

\section{MATERIALS AND METHOD}

This work involved review of previous literatures on the subject, field sampling of soil materials at various sites, and integrated geotechnical laboratory analyses.

A. Review of Literatures. Several literatures, including maps, internet, texts, and journal papers pertinent to the subject of study were consulted. Seeing what people had done provided a better foundation on how to strategize this research.

B. Field Sampling. This involved simultaneous recording of GPS location coordinates and collection of soil samples from different excavation sites. Several samples were collected for analysis. The soils were collected in dry season and at average depth of $40 \mathrm{~cm}$. The materials for the sampling included shovel, hand trowel, sample bags, and labeling gadgets. The samples, at points of collection, were immediately packaged in the sample bags to avoid alterations in their physical makeups. The sample packaging was followed by sample labeling. Eight good samples were collected from eight different towns in the State (Table 1). Samples ABG, NIM, NKA, ORK, and NBI were collected from soil deposits within the Nanka Formation. Samples OZB and OKJ were collected from deposits within the Ogwashi-Asaba Formation; and sample ULI was collected from a deposit within the Benin Formation. These samples were safeguarded and taken to the laboratory, where integrated geotechnical analyses were carried out on each of the samples. 
Table 1 The soil samples, their sampling codes and descriptions

\begin{tabular}{|l|l|l|l|l|}
\hline S/No. & $\begin{array}{l}\text { Sample } \\
\text { Identity/Code }\end{array}$ & $\begin{array}{l}\text { Town of Sample } \\
\text { Collection }\end{array}$ & Sample Description & Geologic Formation \\
\hline 1. & ABG & Abagana & White Sand & Nanka \\
\hline 2. & NIM & Nimo & Gravelly Sand & Nanka \\
\hline 3. & OZB & Ozubulu & Sand-Gravel Mixture & Ogwashi-Asaba \\
\hline 4. & NKA & Nanka & Whitish-Greyish Sand & Nanka \\
\hline $\mathbf{5 .}$ & OKJ & Okija & Sandy Clay & Ogwashi-Asaba \\
\hline 6. & ORK & Oraukwu & White Sand & Nanka \\
\hline 7. & ULI & Uli & Lateritic Sand & Benin \\
\hline 8. & NBI & Nnobi & Lateritic Sand & Nanka \\
\hline
\end{tabular}

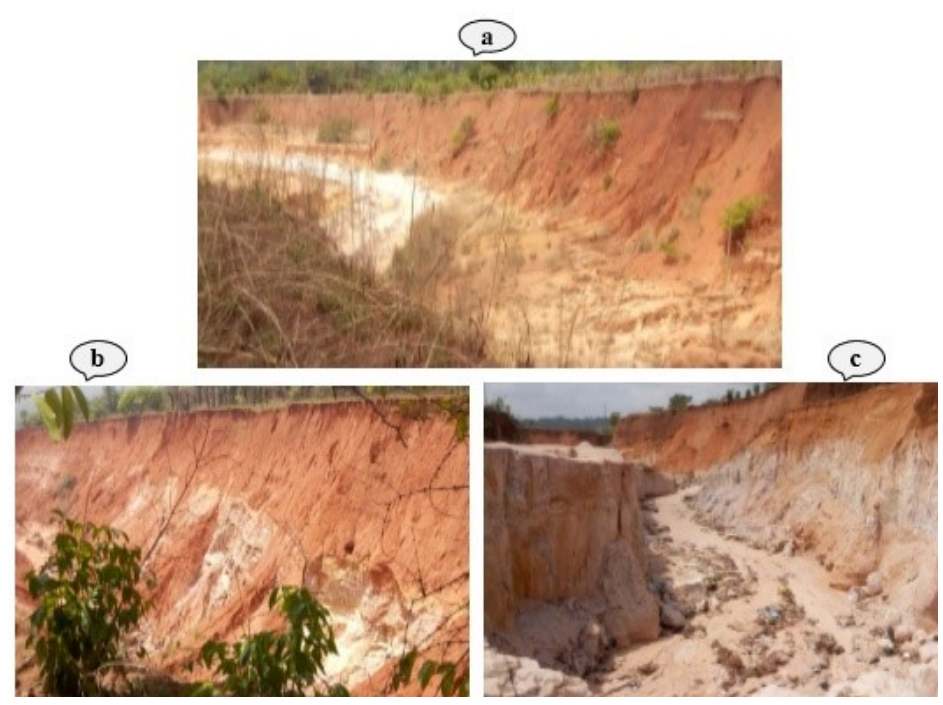

Fig. 2 Excavation sites at (a) Uli, (b) Oraukwu, and (c) Ozubulu

\section{Integrated Geotechnical Analyses}

The physical and mechanical characteristics, which determine the suitability, of soils are primarily revealed and understood by running geotechnical tests on soil samples. This reason informed the choice of the methodology used for this study. Reference [16] pointed out that it is very important to quantify these engineering properties in order to predict how a soil will behave under field loading for safe design of soil structures, as well as other structures that will overly the soil. Following this fact, several geotechnical laboratory analyses were carried out, in order to establish the properties and suitability of the various sampled soil materials. All the tests were systematically carried out in line with the ASTM standards, which are also well described in [16]. The physical qualities tested on the soils are: color, grain size distribution, natural moisture content, permeability coefficient, bulk density (compactness), and specific gravity. The mechanical qualities tested on the soils include: atterberg limits and shear strength. However, these geotechnical properties tested in the laboratory were further grouped into three:

Determination of soil type. This included two laboratory enquiries: (1) Grain size analysis - This was done in order to understand the grain size distribution of the soils. It has been recorded that grain size distribution is a primary factor that defines the engineering character of soils [6][3][7][5][4][13][1]. (2) Laboratory classification of the soils (USCS) - This approach classifies different soils into groups based on their physical and mechanical similarities. The USCS also shows the gradation of soils. Soils with similar gradation often behave in a similar way. Using the USCSone can make decisions about the engineering suitability of different types of soil [9].

Determination of soil material condition. This included the following:(1) Coefficient of permeability test - This test helps to estimate quantity and rate of water seepage/discharge through a soil material [18, p. 129]. It can also help in quantifying pore pressure and volume change of soil, even after compression due to settlement of structures. (2) Compaction testMechanical energy is applied on a soil to rearrange the particles and thus reduce the void ratio. This helps in expressing the variations in density and moisture content during field compaction. It also reveals how porous a soil material is. To predict the performance of compacted soil, and to develop appropriate construction criteria, compaction is performed in the lab using accepted test methods [16]. (3) Natural water content - This expresses the moisture content, in percentages, of a soil. This is primarily used for 
performing weight-volume calculations in soils. It also measures the shrink-swell potentials and strength character. The percentage of water in a soil determines its mechanical behavior when loaded [5][16][1]. (4) Atterberg limits test - These limits are arbitrary boundaries as moisture contents at which the state of a fine grained soil changes. From the limits, the mechanical behavior of soil under stress can be deduced [21][8]. (5) Specific gravity test - This is used for performing weight-volume evaluations in soils [16].

Determination of soil material behavior under loading. Under this, only undrained shear strength test was carried out. Direct shear box test, which provided drained shear properties, was used because the soils were observed to be cohesionless. This test was repeated three consecutive times on each of the soil samples, at the end of which the averages of the parameter were drawn.
IV. RESULTS AND DISCUSSION

\section{A. The Engineering Properties of the Soils}

\section{a. Grain size distribution}

The mechanical sieving revealed the soils' individual structure. Grain size, grain shape, grain distribution (gradation) and grain packing describe the structure of a soil. The grain size analysis revealed that the soils are typically composed of three major fractions fines, sands and gravels (Table 2 and Fig. 3). However, the soils are mainly composed of coarse grains. They generally have low fines content, except for OKJ. OZB has a very high gravel percentage. ORK has more of sand fractions than other grain size fractions. The gradation of the soils is discussed further in the USCS section. The grain shape analysis indicated that they have angular to rounded particles. All the shapes are in varying proportions in the soils. The grain packing analysis showed that the soils are loose materials.

Table 2 Grain size percentages

\begin{tabular}{|l|l|l|l|l|l|l|l|l|l|}
\hline & ABG & NIM & OZB & NKA & OKJ & ORK & ULI & NBI \\
\hline Gravel (\%) & 9.20 & 12.58 & 74.62 & 9.28 & 0.00 & 0.00 & 2.56 & 0.00 \\
\hline Sand (\%) & 75.40 & 72.10 & 20.23 & 75.75 & 41.13 & 96.80 & 74.68 & 79.29 \\
\hline Fines (\%) & 15.40 & 15.32 & 5.15 & 14.97 & 58.87 & 3.20 & 22.76 & 20.71 \\
\hline
\end{tabular}

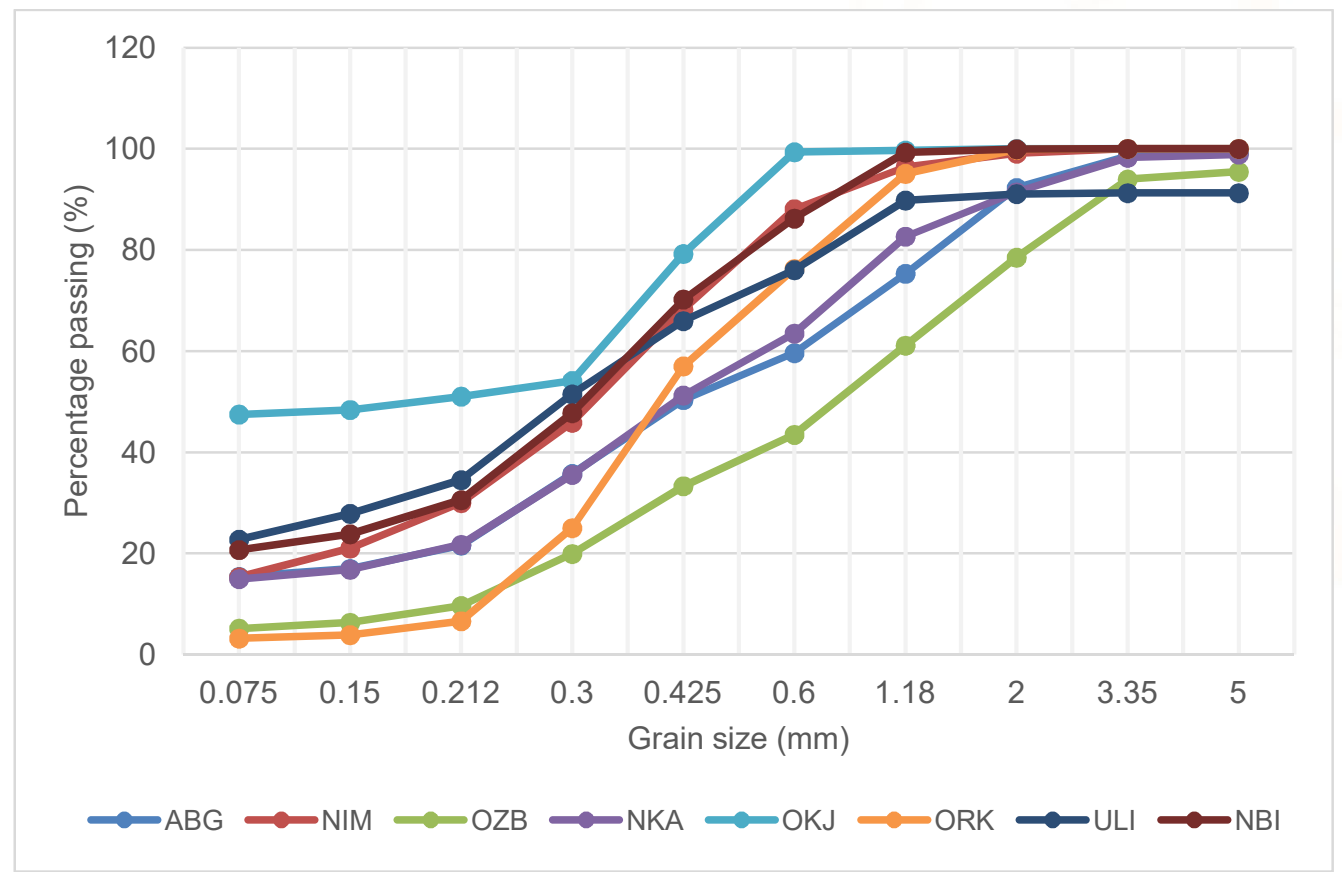

Fig. 3 Stacked grain size distribution curves 


\section{b. Laboratory classification of the soils (USCS)}

The placement of these soils into their various USCS groups followed visual and laboratory examinations. The USCS (Table 3) identified and classified the soils on the basis of texture, plasticity and other behaviors. Five distinct groups of soils were identified from the eight samples. Soils that have similar engineering qualities were classed into same group. The soils generally have zero (negligible) shrink-swell potential and all have Sshaped gradation curves. The grain size fractions and percentages are presented in Table 2.

Table 3 Laboratory USCS of the soils

\begin{tabular}{|c|c|c|c|c|c|c|c|c|c|}
\hline Sample & USCS & $\begin{array}{l}\text { Color \& } \\
\text { Texture }\end{array}$ & $\begin{array}{l}\text { Particle } \\
\text { Fractions }\end{array}$ & $\mathrm{C}_{\mathrm{u}}$ & $\mathrm{C}_{\mathrm{c}}$ & Grading & Plasticity & Organic? & $\begin{array}{l}\text { Compressibility } \\
\text { by compaction }\end{array}$ \\
\hline $\mathrm{ABG}$ & SP & $\begin{array}{l}\text { Whitish- } \\
\text { greyish } \\
\text { clayey } \\
\text { sand }\end{array}$ & Table 2 & Nil & Nil & $\begin{array}{l}\text { Poorly } \\
\text { graded }\end{array}$ & Nonplastic & No & High \\
\hline NIM & SP & $\begin{array}{l}\text { Light } \\
\text { brownish- } \\
\text { grey clayey } \\
\text { sand }\end{array}$ & Table 2 & Nil & Nil & $\begin{array}{l}\text { Poorly } \\
\text { graded } \\
\text { (Non- } \\
\text { uniform) }\end{array}$ & Low & No & High \\
\hline OZB & GP & $\begin{array}{l}\text { Light } \\
\text { Brown } \\
\text { poorly } \\
\text { sorted } \\
\text { sandy- } \\
\text { gravel }\end{array}$ & Table 2 & 3.00 & 0.75 & $\begin{array}{l}\text { Poorly } \\
\text { graded } \\
\text { (Non- } \\
\text { uniform) }\end{array}$ & Nonplastic & No & Low \\
\hline NKA & SP & $\begin{array}{l}\text { Whitish- } \\
\text { greyish } \\
\text { clayey } \\
\text { sand }\end{array}$ & Table 2 & Nil & Nil & $\begin{array}{l}\text { Poorly } \\
\text { graded }\end{array}$ & Low & No & Medium \\
\hline OKJ & $\mathrm{CL}$ & $\begin{array}{l}\text { Dark grey } \\
\text { sandy clay }\end{array}$ & Table 2 & Nil & Nil & $\begin{array}{l}\text { Poorly } \\
\text { graded }\end{array}$ & $\begin{array}{l}\text { Low } \\
(\mathrm{PI}>7 \%)\end{array}$ & $\begin{array}{l}\text { No; } \\
\text { regardless } \\
\text { of the } \\
\text { color }\end{array}$ & Medium \\
\hline ORK & SW & $\begin{array}{l}\text { Light } \\
\text { greyish } \\
\text { sand }\end{array}$ & Table 2 & 1.21 & 1.00 & $\begin{array}{l}\text { Well } \\
\text { graded }\end{array}$ & Nonplastic & No & Low-Medium \\
\hline ULI & $\mathrm{SC}$ & $\begin{array}{l}\text { Reddish } \\
\text { clayey } \\
\text { sand }\end{array}$ & Table 2 & Nil & Nil & $\begin{array}{l}\text { Poorly } \\
\text { graded }\end{array}$ & Nonplastic & No & Medium-High \\
\hline NBI & $\mathrm{SC}$ & $\begin{array}{l}\text { Reddish } \\
\text { clayey } \\
\text { sand }\end{array}$ & Table 2 & Nil & Nil & $\begin{array}{l}\text { Poorly } \\
\text { graded } \\
\text { (Non- } \\
\text { uniform) }\end{array}$ & $\begin{array}{l}\text { Low } \\
(\mathrm{PI}>7 \%)\end{array}$ & No & High \\
\hline
\end{tabular}

\section{c. Coefficient of permeability}

The coefficient of permeability $(\mathrm{k})$ test measured the hydraulic conductivity of the engineering materials. For the eight soils, the $\mathrm{k}$ ranged from $4.22 \times 10^{-6}$ to $4.34 \times 10^{-4}$ (Table 4 ). The permeability result confirmed the grain size distribution of the soils [8, p. 218]. OKJ classed as CL has the lowest permeability while ORK, SW, has the highest. It is observed from the grain size distribution and USCS that increasing content of fines decreases the coefficient of permeability. The CL has the highest content of fines and thus the lowest $\mathrm{k}$. The soils classed SC have a tangible proportion of fines, thus relatively higher permeability than the CL. SP soils have greater 
permeability than the SC soils. The GP soil is the next to the highest permeable soil amongst the samples. SW has the highest $\mathrm{k}$ because it has the lowest percentages of fines (compare Tables 4, 2, and 3). Therefore, the $\mathrm{k}$ increases in the order $\mathrm{CL}<\mathrm{SC}<\mathrm{SP}<\mathrm{GP}<\mathrm{SW}$. This order shows how fast these soils can drain.

\section{Table 4 Coefficient of permeability $(\mathrm{k}, \mathrm{m} / \mathrm{sec})$ result}

\begin{tabular}{|l|l|l|l|l|l|l|l|}
\hline A BG & NIM & OZB & NKA & OKJ & ORK & ULI & NBI \\
\hline $1.64 \times 10^{-4}$ & $5.36 \times 10^{-5}$ & $2.53 \times 10^{-4}$ & $8.52 \times 10^{-5}$ & $4.22 \times 10^{-6}$ & $4.34 \times 10^{-4}$ & $2.86 \times 10^{-5}$ & $4.68 \times 10^{-5}$ \\
\hline
\end{tabular}

\section{d. Compaction result}

The compaction results, presented in Table 5 and Fig. 4, showed that these soils are loose and very porous in their natural state, hence are compressible (compare Table 3 and Fig. 4). Even, it was reasoned that the act of borrowing and transporting the soils will increase their loose nature and thus making them much more porous. Porous materials, such as these, are compacted to improve their engineering properties and behaviors under loading [9]. This attempt increases a soil's density, shear strength, stability, bearing capacity and factor of safety. Informed by these observations and facts, the samples, for the shear strength improvement, were compacted at optimum moisture contents to simulate the best possible field moisture compaction conditions [24][1]. The compaction test defined the maximum dry density and the optimum moisture content (OMC) for the soils. The OMC permitted a given compactive effort to achieve a maximum dry unit weight, for each of the soils (Table 5). It was, therefore, discovered that samples ABG, NIM and NBI required the highest compactive effort. ULI, NKA, and OKJ required a medium compactive effort, whereas OZB and ORK required the lowest compactive effort, amongst the samples (Fig. 4)[8, p. 289][16, p. 77].

Table 5 Compaction result

\begin{tabular}{|l|l|l|l|l|l|l|l|l|}
\hline & ABG & NIM & OZB & NKA & OKJ & ORK & ULI & NBI \\
\hline MDD $\left(\mathrm{g} / \mathrm{cm}^{3}\right)$ & 1.91 & 1.88 & 1.76 & 1.88 & 1.89 & 1.84 & 1.94 & 1.89 \\
\hline OMC $(\%)$ & 13.29 & 13.91 & 15.23 & 17.10 & 17.06 & 15.28 & 13.99 & 14.12 \\
\hline $\begin{array}{l}\text { Bulk Density } \\
\left(\mathrm{g} / \mathrm{cm}^{3}\right)\end{array}$ & 1.75 & 1.75 & 1.90 & 1.77 & 1.83 & 1.68 & 1.86 & 1.86 \\
\hline
\end{tabular}




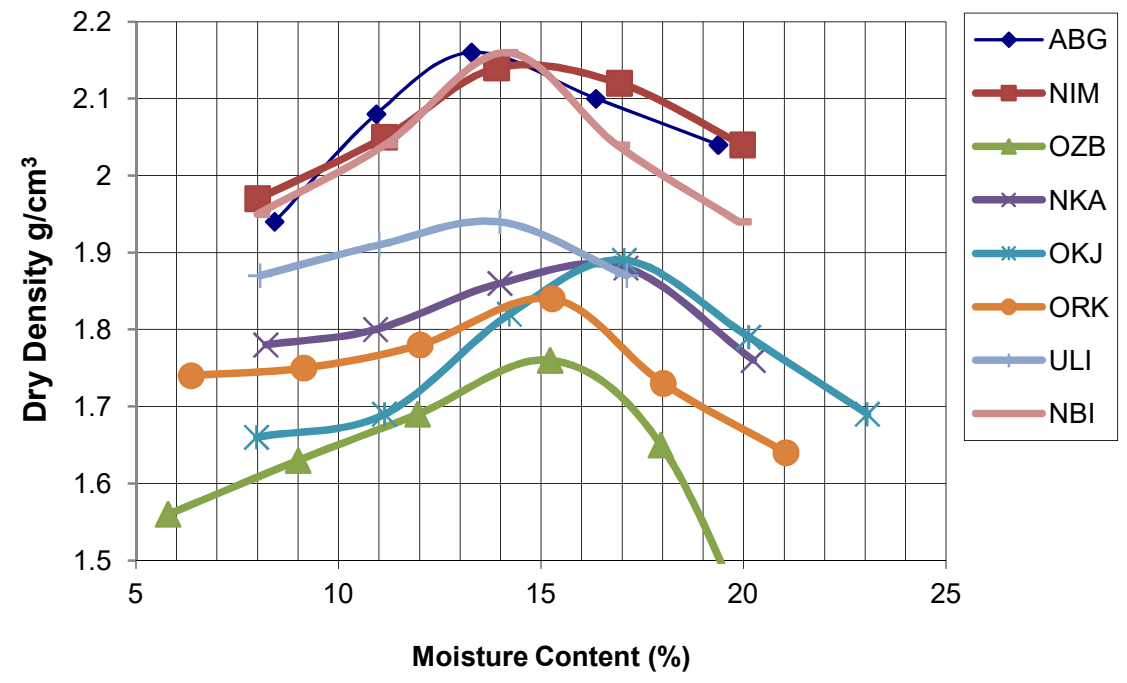

Fig. 4 Stacked compaction curves for the soils

\section{e. Natural water content and Atterberg limits}

The water content test revealed that the water contained in a material grossly determines its engineering characteristics and behaviors. The amount of water in a soil determines its deformation or failure path. This behavior is summed up as the soil's consistency. Table 6 presents the results from the natural water content and atterberg limit tests. These soils generally have very low moisture content. This could point to the fact that they were sampled in dry season [15]. The moisture content confirmed, as demonstrated in the liquid limit and plastic limit testing, that the soils have zero shrink-swell potential.

The atterberg limits of the fines showed that they are nonplastic to low plastic materials. Inelasticityof these soils is a character that suggests that they would not regain totalinitial volume on unloading [5, p. 7]. The low PI value of the fines is also a pointer to their mineralogical makeup. This then suggests that the clay minerals are likely of the kaolinite family, thus having a zero shrink-swell potential, than other clay mineral groups. These fines are noncohesive and this points to why the soils (except OKJ) have higher frictional angles than cohesion (Table 7). The consistency indices, which measures the degree of coherence between soil particles at a given water content, show values that are very close to negative; hence explaining why the soils couldn't behave as liquid, but only as soft to hard material. The observations also suggest that since the soilsgenerally have relatively similar consistency, they would all behave in a similar manner when extra water is added to them[1]. However, it is pertinent to note that excess water content (and some other external factors) can interfere their consistency.

Table 6 Water content, atterberg limits and consistency indices

\begin{tabular}{|l|l|l|l|l|l|l|l|l|}
\hline & ABG & NIM & OZB & NKA & OKJ & ORK & ULI & NBI \\
\hline$w(\%)$ & 2.00 & 3.00 & 1.61 & 3.00 & 3.00 & 1.61 & 3.00 & 3.00 \\
\hline$L L(\%)$ & 25 & 25 & NP & 22 & 32 & NP & 24 & 25 \\
\hline$P L(\%)$ & NP & 16 & NP & 12 & 19 & NP & NP & 14 \\
\hline$P I(\%)$ & NP & 9 & NP & 10 & 12 & NP & NP & 11 \\
\hline$L I(\%)$ & 0.00 & 1.22 & 0.00 & -0.90 & -1.33 & 0.00 & 0.00 & 1.73 \\
\hline$C I(\%)$ & 0.00 & 2.00 & 0.00 & 1.90 & 2.42 & 0.00 & 0.00 & 2.44 \\
\hline
\end{tabular}




\section{f. Specific gravity}

The soils have close ranged values of specific gravity, from 2.55 to 2.69 (Fig. 5). Soils with similar specific gravity show similarity in textural and mineralogical makeup [1]. These soils are mainly medium-coarse grained materials (except for OKJ). This suggests that, based on weight-volume estimations, they would behave in a similar manner. The GP (OZB) and the SW (ORK) soils have specific gravity of 2.55 and 5.56 respectively, which are very close to the values, $2.3-2.5,[9, \mathrm{p} .26]$ classed as silts. The low specific gravity of the GP and SW could be because of (1) dominance of angular particles in the soils [9, p.18], and (2) very low percentages of heavy fine (clay) minerals in them (compare Table 2 and Fig. 5).

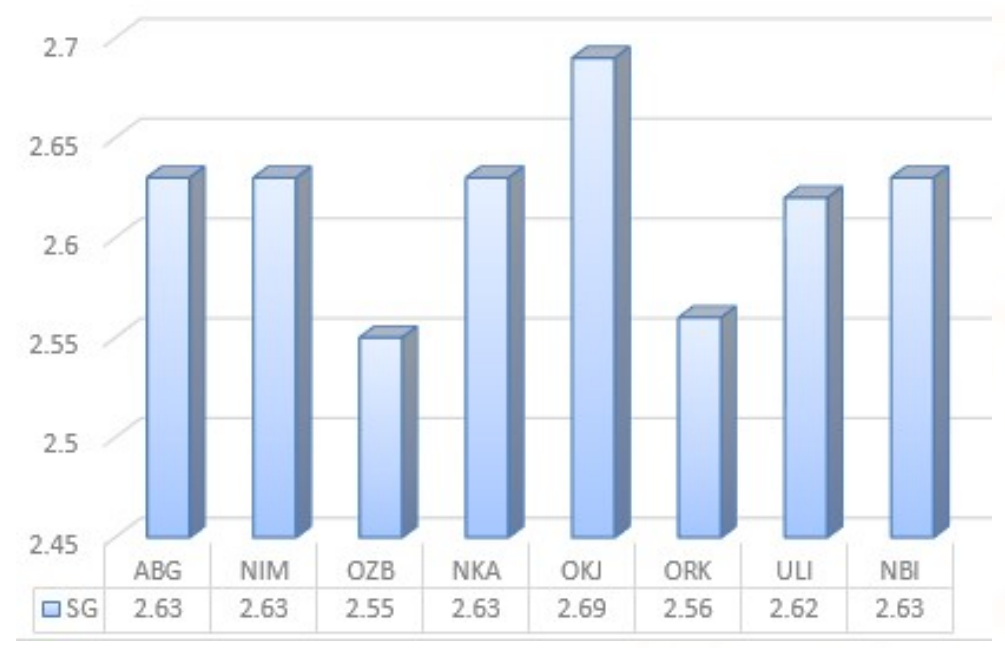

\section{g. Direct shear strength test}

Fig. 5 Specific gravity result for the soils

This is a fundamental engineering parameter that measured the response (behavior) of the soil materials to shearing stresses. It expresses shearing stress as a function of load. Table 7 presents the shear strength parameters (behaviors) obtained from the direct shear test. Generally, the soils have low cohesion but high frictional angle, except for the OKJ which has a cohesion of $27.31 \mathrm{kPa}$ and $19.34^{\circ}$ angle of internal friction. The low cohesion is believed to be attributed to (1) the low percentages of fines (as shown in the grain size analysis), (2) low water content, and (3) the presence of nonplastic and low plastic fines (compare Tables 7, 2 and 6). [8, p. 165] pointed out that the presence of cohesion may be used to divide soils into two classes, namely cohesive and non-cohesive soils. On this note, these soils can be generally classed as non-cohesive soils; though an increase in their water content (to a certain point and for a long period of time) could increase the cohesion of the soils, especially for the OKJ. The mild increase in water content causes the cohesion increment by (1) increasing plasticity of the fines, and (2) expediting weathering processes that lead to disintegration of particles into finer clay sizes.

Table 7 Selected shear strength parameters of the soils

\begin{tabular}{|l|l|l|l|l|l|l|l|l|}
\hline Cohesion, C (kPa) & A BG & NIM & OZB & NKA & OKJ & ORK & ULI & NBI \\
\hline $\begin{array}{l}\text { Angle of internal } \\
\text { friction, Ø( }\end{array}$ & 36.20 & 3.28 & 5.55 & 6.72 & 27.31 & 0.66 & 6.40 & 6.41 \\
\hline $\begin{array}{l}\text { Average Normal } \\
\text { Stress (kPa) }\end{array}$ & 54.50 & 54.50 & 54.50 & 54.50 & 54.50 & 54.50 & 54.50 & 54.50 \\
\hline \begin{tabular}{l} 
Peak Strength (kPa) \\
\hline $\begin{array}{l}\text { Average Horizontal } \\
\text { Displacement (mm) }\end{array}$
\end{tabular} & 40.57 & 41.73 & 47.10 & 41.10 & 46.50 & 41.33 & 38.83 & 41.33 \\
\hline $\begin{array}{l}\text { Average Rate of } \\
\text { Shear Displacement } \\
\text { (mm/min) }\end{array}$ & 0.6852 & 1.1548 & 0.5166 & 1.0145 & 0.7186 & 0.6631 & 0.7718 & 1.1051 \\
\hline
\end{tabular}




\section{B. Suitability of these Soils as Backfill Materials}

Having seen the engineering properties of these soils, we shall now assess their suitability as backfilling (embankment, foundation, subgrade, and orbase) materials (Tables 8, 9, 10, 11, and 12).

\section{a. Suitability based on soil type}

On the basis of fines content, SC and CL soils have the least engineering integrity as backfill materials. Reference [8] reported that deposits of sand and gravel will not be suitable sources of aggregate when they contain contaminating substances, such as clay, in quantities that can adversely affect its performance. Cleaner coarse materials (SW, GP, and SP soils) have much more engineering integrity as backfilling aggregates. This is true because they have the highest frictional angle, thus they have the highest shear resistance (strength) coming from the interlocking between their grains (compare Tables 3 and 7). The clayey soils, especially the CL (OKJ), have the tendency of deforming easily under static load, but have the tendency for more stability when loaded with vibratory loads [3].

As revealed by the grain shape analysis, the soils generally have angular to round grain shapes. This suggests that they can serve as backfill materials. However, it is pertinent to note that angular particles have greater shear strength than the rounded counterparts, because grains find it difficult to slide over one another. This also suggests that the former have higher angle of internal friction than the latter. Though, on the contrary, angular soil particles have much more tendency of fracturing than their rounded counterparts. On the basis of grain packing, the result presented showed that the soils are loose. Often, loose soils present a big problem in engineering constructions, especially when used as base, subgrade, and or foundation aggregates. They often cause quick and differential settlement of structures, which defiantly lead to failures, loss of lives and economic wastes. However, these very porous, loose materials need compaction for their packing to be tighter. The tighter the grain packing of the soils, the more their suitability as engineering construction materials.

\section{b. Suitability based on soil material natural condition}

From the coefficient of permeability result, which varied from one soil to another, the soils are quite permeable. The ability of the soils to drain water away is a good quality as engineering materials [16][1]. In line with this thought, they are good foundation and subgrade materials, especially the GP, SW, and SP soils. Contrary to this, it is very pertinent to note that permeable materials are not always good materials for certain construction works. These soils would experience high pore-water pressure, if they, by chance, are exposed to saturation (in confined state) and loaded under the same condition. When this is the case, the pore-water pressure will reduce their strength. Thus, the behavior of those soils with negligible cohesion (Table 7) would appear like this: $\tau$ $=(\sigma-u)$ tan $\varnothing$; but the OKJ with highest cohesion but lowest angle of resistance would appear like this: $\tau=$ $c+(\sigma-u)$ tan $\varnothing ;$ where $\tau=$ shear strength, $\sigma=$ normal/total stress, $\mathrm{u}=$ pore pressure, and $\varnothing=$ angle of internal friction $[3][4][8][9]$.

Generally, the water content of the soils is quite low (Table 6). This, therefore, is a good engineering property of these soils, when considered as backfilling materials. The presence of excess water in the pores of soils lessens the cohesion and the forces of friction between grains. Increase in water content decreases the strength of a soil [5, p. 7]. The negligible shrinkswell potential of the soils, which was also determined from the water content and plasticity results, makes them much better engineering materials for backfilling purposes. The consistency indices, which measured very close to negative explains that the soils wouldn't behave as liquid, but only as soft or hard material. This also suggests a good engineering quality. In order to maintain these qualities, the best practice is to keep these soils from excess water contact, which would interfere with their consistency, thus their engineering behaviors and suitability [1].

The specific gravity, as well as the bulk density, moisture content and loose nature, of the soils is a significant property required when choosing mixing proportions in backfilling projects. The specific gravity results of the GP and SW soils, firstly, suggested the dominance of angular particles in their structures and, secondly, buttressed the fact that they have low heavy clay mineral content. These, in turn, suggest that, among the eight soils, these two soils are the most suitable materials for backfilling [5]. However, all the soils, under some conditions, will make good aggregates for backfilling, especially if they retain their mass even when exposed to varying environments. 
Notwithstanding the good qualities already described about these soils, they are yet subject to improvement, since they have high void ratios. For the engineering properties and suitability of these soils to be improved, compaction is very essential. An attempt to compact them, at their individual MDD and OMC, will definitely improve their behaviors and suitability by increasing their density, shear strength, bearing capacity, stability, and factor of safety. Other things being equal, the compaction of these soils would rearrange them, based on backfilling suitability, in this order: $\mathrm{SW}>\mathrm{GP}>\mathrm{SP}>\mathrm{SC}>\mathrm{CL}$. GP soil could have been the most suitable, but its gradation is the hindrance (Tables 8\&9). The materials, if not compacted and loaded, would deform rapidly, when its grains move under the influence of an applied load [8, p. 161]. This deformation will result because of a quick rearrangement and settlement of the grains and imposed structure, i.e. the load. The compactive efforts revealed in the compaction result allows for an informed choice when choosing a compactor in the field.

\section{c. Suitability based on soil material behavior under loading}

For the shear strength of backfilling materials, the angle of internal friction plays a better role than the cohesion. This ideology is in line with the fact that higher fines content increases cohesion but decreases the engineering performance of soil materials [8][4][9, p. 246-247]. Therefore, on the basis of shear resistance, these soils are considered good backfilling materials; though OKJ has the least shear resistance. The bearing capacity of these soils increases with increasing unweathered grain sizes. For the soils with insignificant cohesion (Table 7), the shear behavior (in drained condition) will likely take this path: $\tau=$ $\sigma$ 'tanø, whereas that of the OKJ with highest cohesion but lowest frictional angle (in a mildly increased water content) would likely take this path when loaded: $\tau=\mathrm{c}+\sigma^{\prime} \tan \varnothing$; where $\tau=$ shear strength, $\sigma^{\prime}=$ effective stress, $\mathrm{c}=$ cohesion, and $\varnothing=$ angle of internal friction. The strength of these materials will steadily increase with an increasing stress (load), up to a point (the peak strength) whereby they fail (Tables 7 and 3).

Table 8 Key properties considered in suitability assessment (adapted from USCS Appendix-B; Wagner, 1957; Budhu, 2015)

\begin{tabular}{|c|c|c|c|c|c|c|c|}
\hline Sample & USCS & Workability & $\begin{array}{l}\text { Compressibility } \\
\text { after } \\
\text { compaction } \\
\text { and when } \\
\text { saturated }\end{array}$ & $\begin{array}{l}\text { Permeability } \\
\text { when } \\
\text { compacted }\end{array}$ & $\begin{array}{l}\text { Plasticity } \\
\text { of fines } \\
\text { content }\end{array}$ & $\begin{array}{l}\text { Shearing } \\
\text { strength } \\
\text { when } \\
\text { compacted } \\
\text { and } \\
\text { saturated }\end{array}$ & $\begin{array}{l}\text { Erosion } \\
\text { resistance }\end{array}$ \\
\hline $\mathrm{ABG}$ & SP & Fair & Very low & $\begin{array}{l}\text { Good } \\
\text { excellent }\end{array}$ & Nonplastic & Good & Medium \\
\hline NIM & SP & Fair & Very low & $\begin{array}{l}\text { Good } \\
\text { excellent }\end{array}$ & Low & Good & Medium \\
\hline OZB & GP & Good & Almost none & Excellent & Nonplastic & Good & Low \\
\hline NKA & SP & Fair & Very low & $\begin{array}{ll}\text { Good } & \text { to } \\
\text { excellent }\end{array}$ & Low & Good & Medium \\
\hline OKJ & $\mathrm{CL}$ & Good to fair & Medium & $\begin{array}{l}\text { Very poor to } \\
\text { impervious }\end{array}$ & $\begin{array}{l}\text { Low } \\
(\mathrm{PI}>7 \%< \\
20 \%)\end{array}$ & Fair & High \\
\hline ORK & SW & Excellent & Almost none & Excellent & Nonplastic & Excellent & $\begin{array}{l}\text { Medium- } \\
\text { High }\end{array}$ \\
\hline ULI & $\mathrm{SC}$ & Good & $\begin{array}{l}\text { Slight } \\
\text { medium }\end{array}$ & $\begin{array}{l}\text { Poor to } \\
\text { impervious }\end{array}$ & Nonplastic & $\begin{array}{l}\text { Good to } \\
\text { fair }\end{array}$ & Medium \\
\hline NBI & $\mathrm{SC}$ & Good & $\begin{array}{l}\text { Slight } \\
\text { medium }\end{array}$ & $\begin{array}{l}\text { Poor to } \\
\text { impervious }\end{array}$ & Low & $\begin{array}{l}\text { Good to } \\
\text { fair }\end{array}$ & Medium \\
\hline
\end{tabular}


International Journal of Trend in Scientific Research and Development (IJTSRD) ISSN: 2456-6470

Table 9 Backfilling suitability of the soils (adapted from USCS Appendix-B; Wagner, 1957; and Budhu, 2015; p. 52)

\begin{tabular}{|l|l|l|l|l|l|l|}
\hline Sample & USCS & $\begin{array}{l}\text { Value for } \\
\text { embankment }\end{array}$ & $\begin{array}{l}\text { Bearing capacity } \\
\text { value for } \\
\text { foundation }\end{array}$ & $\begin{array}{l}\text { Value as sulograde } \\
\text { when not suloject } \\
\text { to frost action }\end{array}$ & $\begin{array}{l}\text { Value as base when } \\
\text { not subject to frost } \\
\text { action }\end{array}$ \\
\hline ABG & SP & Reasonably stable & $\begin{array}{l}\text { Good to poor, } \\
\text { depends on density }\end{array}$ & Fair to good & Poor to not suitable \\
\hline NIM & SP & Reasonably stable & $\begin{array}{l}\text { Good to poor, } \\
\text { depends on density }\end{array}$ & Fair to good & Poor to not suitable \\
\hline NKA & SP & Reasonably stable & $\begin{array}{l}\text { Good to poor, } \\
\text { depends on density }\end{array}$ & Fair to good & Poor to not suitable \\
\hline OKJ & CL & Stable & Good to poor & Poor to fair & Not suitable \\
\hline ORK & SW & Very stable & Good to excellent & Good & Poor to fair & Not suitable \\
\hline ULI & SC & Fairly stable & Good to poor & Good to poor & Poor to fair & Not suitable \\
\hline NBI & SC & Fairly stable & & Good to & Food \\
\hline
\end{tabular}

Table 10 Embankment and foundation suitability of the soils based on NFMWH*2003 Standard

\begin{tabular}{|c|c|c|c|c|c|c|c|c|c|c|}
\hline \multirow[b]{2}{*}{ Parameter } & \multirow[b]{2}{*}{$\begin{array}{l}\text { NFMWH } \\
\text { Value }\end{array}$} & \multicolumn{8}{|c|}{ Sample Value } & \multirow[b]{2}{*}{ Remark } \\
\hline & & ABG & NIM & OZB & NKA & OKJ & ORK & ULI & NBI & \\
\hline $\begin{array}{l}\mathrm{MDD} \\
\left(\mathrm{g} / \mathrm{cm}^{3}\right)\end{array}$ & $>0.04$ & 1.91 & 1.88 & 1.76 & 1.88 & 1.89 & 1.84 & 1.94 & 1.89 & \multirow{5}{*}{$\begin{array}{l}\text { All the } \\
\text { tropical soils } \\
\text { are good for } \\
\text { embankment } \\
\text { and } \\
\text { foundation } \\
\text { filling }\end{array}$} \\
\hline OMC (\%) & $<18$ & 13.29 & 13.91 & 15.23 & 17.10 & 17.06 & 15.28 & 13.99 & 14.12 & \\
\hline LL $(\%)$ & $<40$ & 25 & 25 & NP & 22 & 32 & NP & 24 & 25 & \\
\hline PI (\%) & $<20$ & NP & 9 & NP & 10 & 12 & NP & NP & 11 & \\
\hline Fines $(\%)$ & $\leq 35$ & 15.40 & 15.32 & 5.15 & 14.97 & 58.87 & 3.20 & 22.76 & 20.71 & \\
\hline
\end{tabular}

* Nigerian Federal Ministry of Works and Housing

Table 11 Sub-grade suitability of the soils based on NFMWH 2003 Standard

\begin{tabular}{|c|c|c|c|c|c|c|c|c|c|c|}
\hline \multirow[b]{2}{*}{$\begin{array}{l}\text { Paramete } \\
\mathbf{r}\end{array}$} & \multirow[b]{2}{*}{$\begin{array}{l}\text { NFMWH } \\
\text { Value }\end{array}$} & \multicolumn{8}{|c|}{ Sample Value } & \multirow[b]{2}{*}{ Remark } \\
\hline & & ABG & NIM & OZB & NKA & OKJ & ORK & ULI & NBI & \\
\hline LL (\%) & $<35$ & 25 & 25 & NP & 22 & 32 & NP & 24 & 25 & \multirow{2}{*}{$\begin{array}{l}\text { All are good } \\
\text { sub-grade } \\
\text { materials }\end{array}$} \\
\hline PI (\%) & $<16$ & NP & 9 & NP & 10 & 12 & NP & NP & 11 & \\
\hline
\end{tabular}


Table 12 Base suitability of the soils based on NFMWH 2003 Standard

\begin{tabular}{|c|c|c|c|c|c|c|c|c|c|c|}
\hline \multirow[t]{2}{*}{ Parameter } & \multirow{2}{*}{$\begin{array}{l}\text { NFMWH } \\
\text { Value }\end{array}$} & \multicolumn{8}{|c|}{ Sample Value } & \multirow[t]{2}{*}{ Remark } \\
\hline & & ABG & NIM & OZB & NKA & OKJ & ORK & ULI & NBI & \\
\hline LL (\%) & $\leq 30$ & 25 & 25 & NP & 22 & 32 & NP & 24 & 25 & \multirow{3}{*}{$\begin{array}{l}\text { The soils are } \\
\text { poor base } \\
\text { materials. } \\
\text { However, } \\
\text { OZB, NKA, } \\
\& \text { ORK are } \\
\text { fairly good }\end{array}$} \\
\hline PI (\%) & $\leq 13$ & NP & 9 & NP & 10 & 12 & NP & NP & 11 & \\
\hline Fines (\%) & $5-15$ & 15.40 & 15.32 & 5.15 & 14.97 & 58.87 & 3.20 & 22.76 & 20.71 & \\
\hline
\end{tabular}

\section{Factors That Can Influence the Properties and Suitability of These Soils}

The engineering properties of soil materials are not static, but dynamic. The properties and behaviors of soils change as the factors influencing them change. These soils are not an exception; several factors can influence them too. Those factors that can influence the engineering qualities and suitability (the strength) of these soils, when used as backfilling aggregates are discussed below. These factors can act singly or in combination.

i. Method and extent of compaction. Sand and gravel materials exhibit high bearing capacity and negligible compressibility when compacted, but low bearing capacity and high compressibility when loose [18]. The method (or machinery) used in the compaction of these soils will reflect the extent of grain rearrangements, and would thus influence the behavior of these materials. These soils, if compacted below their MDD's and OMC's, would have shifts in their engineering behaviors. The extent of compaction, thus, determines the performance of these soils as backfilling materials. For instance, overcompaction should be avoided, as this may increase susceptibility of the soils to shrinkage [6].

ii. Blending. This involves improving the poor grading of a material by adding to it the grain sizes missing from the mixture [18]. For the poorly graded soils, blending will go a long way in making them excellent engineering materials.
This would directly alter the original behavior of those soils.

iii. Presence of admixtures or additives. Some additives, such as Portland cement, are sometimes used alongside soils and other aggregates in backfilling projects, in order to achieve engineering and economic objectives. Such substances, when added to these soils, will definitely influence their engineering performance. However, care should be taken when adding chemicals such as sulphates. Some additives tend to reduce the ultimate strength of aggregates soils.

$i v$. Presence of organic impurities. If by chance organic matters are introduced into these soils (maybe, during the act of borrowing them), their engineering integrity will become questionable. Such organic impurities will critically interfere with the original behaviors of these soils. Therefore, care should be taken when these soils are being excavated, to avoid inclusion of organic matters.

v. Geochemistry of water to be used. Water for the compaction of these soils shouldn't test acidic. Acidic water will react in a bad manner to the engineering characteristics of these soils. In such a scenario, chemical weathering would be expedited in the soils.

vi. Hydrology and infiltration rate. Inasmuch as the good drainage characteristics of these soils have been mentioned (Table 8), great care should be taken to keep them from excess water. If these soils are used in areas with excessive rainfall or in waterlogged areas, excess infiltration/percolation 
would cause pore water to build up, thereby annulling the shear strength of these materials. For instance, the CL soil has reasonable bearing capacity and moderate compressibility, but it is liable to soften when wetted [18].

vii. Degree of weathering. If the borrowed materials are exposed to environments where the rate of weathering is high, their shear behavior will change over time. Such process will decrease the shear integrity of the soils.

viii. Loading These soils don't have the same bearing capacity, having noted the differences in their engineering properties (Table 9). They will respond different to vertical loading (dead, downdrag, or live loads), lateral loading (fluid pressures or lateral earth pressures), or moving/dynamic loading. The rate, weight, design and specifications of loading have the potential of influencing the response of these soils. Fast rate of loading, improper load designs, and overloading would cause these soils to respond negatively. Reference [4] noted that the settlement of particles (downdrag loading) in noncohesive soils is faster than in cohesive soils. Therefore, if these soils are not well compacted, before loading, they will behave hazardously. Such a scenario will cause quick settlement of engineering structures, which often leads to disaster.

ix. Depth to be backfilled and the hydrogeological conditions of the location. Areas with shallow water table, where capillary rise is possible, will pose great risk to the engineering suitability (behaviors) of these soils. As more water enter the soil systems, their engineering integrity depreciates. These soils can only maintain good engineering status in water-logged areas and in areas with shallow water table, if the depth or thickness of the backfilling is large enough. The large thickness would prevent/reduce the effects of upward seepage (capillary rise) of water which would alter the engineering properties and suitability of the soils. Moreover, employing some soil stabilization techniques will help improve the soils in such scenario.

$x$. Properties of surrounding soil/rock. Soils adjacent to the structure, where these soils have been used for backfilling, can influence them in many ways. For instance, neighboring soil/rock that is highly permeable has the potential to influence the water content of these soils, even when they have been well compacted. $x i$. Angle of inclination. If these soils are intended to be used as embankment materials, the slope angles should be critically considered; especially when stabilization of slope is not factored into the project. Since, they have lower cohesion (except for $\mathrm{OKJ}$ ), and thus noncohesive, they can easily be eroded by water at medium to high slope angles (Table 8). The water infiltrating the soils would lubricate the grains, thus reducing their frictional angle and making the grains to easily slide over one another and erode.

xii. Maintenance. Continuous check on the structures built on these materials keeps their suitability/integrity and factor of safety intact. If the structures, like subgrade (road) and embankment, are not maintained, the good properties and integrity of these soils will be hampered.

\section{CONCLUSIONS}

Based on the geotechnical findings (summarized in Tables 8, 9 and 10), the following conclusions are made:

i. The eight soils are dominantly composed of coarse grains. The laboratory USCS grouped these soils into five classes - GP (OZB), SW (ORK), SP (ABG, NIM, and NKA), SC (ULI and $\mathrm{NBI})$, and $\mathrm{CL}(\mathrm{OKJ})$ soils. Their coefficients permeability ranged from $4.22 \times 10^{-6}$ to $4.34 \times 10^{-4}$, expressing that they are permeable materials. The compaction test provided the MDD and OMC for the soils. It showed that samples ABG, NIM and NBI require the highest compactive effort. ULI, NKA, and OKJ require a medium compactive effort, whereas OZB and ORK require the lowest compactive effort, amongst the samples. The soils have low natural moisture content, ranging from $1.61-8.00 \%$. The atterberg limits of the fines showed that they are nonplastic to low plastic materials, with the highest PI as $12 \%$ (for the CL soil). The specific gravity ranged from 2.55-2.69. The soils have low cohesion $(0.66-6.72 \mathrm{kPa})$ but high shear resistance $\left(32.54-36.47^{\circ}\right)$, except for the CL soil which has a cohesion of $27.31 \mathrm{kPa}$ and $19.34^{\circ}$ friction angle. The cohesion of the soils decrease with decreasing percentages of fines.

ii. Generally, these soils have good engineering properties (even though the properties vary), and thus can serve as better aggregates for backfilling, especially for foundation, subgrade and 
embankment purposes. They are generally not suitable as base materials. However, their engineering properties and suitability can be improved by compaction and other soil stabilization techniques, especially if the intended use is centered on sub-grading, foundation and or embankment. Other things being equal, compaction, without blending, of these soils would rearrange them, based on engineering suitability, in the order $\mathrm{SW}>\mathrm{GP}>\mathrm{SP}>\mathrm{SC}>\mathrm{CL}$.

iii. Having noted the acceptable engineering qualities of these soils, enough care should be taken to reduce the chances and effects of those factors that can alter their qualities. This will keep their suitability and factor of safety intact.

\section{RECOMMENDATIONS}

The following advice are very important when using (or intending to use) these soils as aggregates. They allow for an informed choice.

i. As the soils, except ORK, are not well graded, it is advisable to blend (using equal proportions of different particle sizes).This will enhance compaction and reduce segregation of plastic concrete.

ii. For use in major construction projects, such as multi-storeyed buildings and heavy airfields, it is advised that further elaborate tests be carried out to further characterize the properties and suitability of these soils, before they are used in such projects.

iii. Finally, it is recommended that the building codes and standards of the locations where these materials are intended to be used be consulted and strictly adhered to.

\section{REFERENCES}

1. Ameh, P.D.; Igwe, O.; Ukah, B.; (2016) Evaluation of the bearing capacity of near-surface soils using integrated methods: a case study of Otukpa, Ogbadibo LGA Benue State, NorthCentral Nigeria.Jour. Geol. Soc. India,(in press).

2. Aqil, U.; Tatsuoka, F.; Uchimura, T.;Lohani, T.N.; Tomita, Y.; Matsushima, K. (2005) Strength and deformation characteristics of recycled concrete aggregate as backfill material. Soils and Foundations 45(5):53-72.
3. Arora, K.R.;(2003) Soil mechanics and foundation engineering, $6^{\text {th }}$ Ed. Standard Publishers Distributors, Delhi.

4. Arora, K.R.;(2008) Soil mechanics and foundation engineering (Geotechnical Engineering), $8^{\text {th }}$ Ed. Standard Publishers Distributors, Delhi.

5. Atkinson, J.H.; (2007) Themechanics of soils and foundations, $2^{\text {nd }}$ Ed. Taylor \& Francis, New York.

6. Bell, F.G.; (1999) Geologic hazards: their assessment, avoidance and mitigation. E \& FN SPON, London.

7. Bell, F.G. (2007); Engineering Geology, $2^{\text {nd }} E d$. Butterworth-Heinemann, Elsevier Ltd, Oxford UK.

8. Blyth, F.G.H.; de Freitas, M.H.; (2005) A Geology for Engineers, $7^{\text {th }}$ Ed. ButterworthHeinemann, Great Britain.

9. Budhu, M.; (2015) Soil mechanics fundamentals. John Wiley \& Sons, United Kingdom.

10. Celestin, J.C.H.; Fall, M; (2009) Thermal conductivity of cemented paste backfill material and factors affecting it. International Journal of Mining, Reclamation and Environment 23(4):274290.

11. Egboka, B.C.E.; Okpoko, E.I.; (1984) Gully erosion in the Agulu-Nanka region of Anambra State, Nigeria. Challenges in African Hydrology and Water Resources: Proceedings of the Harare Symposium, IAHS Publ. 144:335-347.

12. Hudec, P.P.; Simpson F.; Akpokodje, E.G.; Umenweke, M.O.; (2006) Termination of gully processes, Southeastern Nigeria.

PROCEEDINGS of the Eighth Federal Interagency Sedimentation Conference $\left(8^{\text {th }}\right.$ FISC), April2-6, 2006, Reno, NV, USA 671-679.

13. Ibeneme, S.I.;Idiong, I.A.; Nwagbara, J.O.; Selemo, A.O.; Israel, H.O.; (2014) Assessment of the engineering significance of geo-materials derived from a borrow pit at UgwuOrlu, SouthEast Nigeria. Int. Res. J. Geo. Min 4(1):1-8.

14. Igwe, O.; (2015) The causes and mechanisms of rain-induced highway and pavement collapse in Obolo-eke, Southeast Nigeria. Arab J Geosci. doi: 10.1007/s12517-015-1899-z

15. Jegede, O.G.; Olaleye, B.M.; (2013) Evaluation of engineering geologic and geotechnical properties of sub grade soils along re-aligned Igbara-Ikogosi 
highway, South-west Nigeria. International Journal of Engineering and sciences 2(5):18-21.

16. Kalinski, M.E.; (2011) Soil mechanics lab manual, $2^{\text {nd }}$ Ed. John Wiley \& Sons, Inc. United States of America.

17. Komine, H.; (2004) Simplified evaluation on hydraulic conductivities of sand-bentonite mixture backfill. Applied Clay Science 26(1):13-19.

18. Krynine, D.P.; Judd, W.R.; (2001) Principles of Engineering Geology and Geotechnics. CBS Publishers and Distributors, New Delhi.

19. Maail, S.;Huat, B.B.K.; Jamaludin, S.; (2004) Index, engineering properties and classification of tropical residual soils. In: Sew GS, Ali FH, and Huat BBK (eds.) Tropical Residual Soils Engineering, Taylor and Francis, London pp. 3755. doi: 10.1201/9780203024621.ch3

20. Madukwe, H.Y.; Bassey, C.E.; (2015) Geochemistry of Ogwashi-Asaba Formation, Anambra Basin, Nigeria: implications for provenance, tectonic setting, source area weathering, classification and maturity. IJST 4(7):312-327.

21. Nnamani, C.H.; Igwe, O.; (2016) Undrained saturated expansive soil: a case study of Awgu Shalein Oji-Agu Akpugo Southeastern Nigeria. Jour.Geol.Soc.India, 87:222-226.

22. Nwajide, C.S.; (2013) Geology of Nigeria's Sedimentary Basins. CSS Bookshops Limited, Nigeria.
23. Obaje, N.G.; (2009) Geology and mineral resources of Nigeria. Springer-Verlag Berlin Heidelberg, New York.

24. Odoh, B.I.; Egboka, B.C.E.; Aghamelu, P.O.; (2012)The status of the soil at the permanent site of Nnamdi Azikiwe University, Awka, SE Nigeria. Canadian Journal of Pure and Applied Sciences 6(1):1837-1845.

25. Ola, S.A.; (1978a) Geotechnical properties and behaviors of stabilized lateritic soils. Quarterly Journal of Engineering 11:145-160.

26. Ola, S.A.; (1978b) The geology and engineering properties of black cotton soils in northeastern Nigeria. Engineering Geology 12:375-391.

27. Ola, S.A.; (1980) Mineralogical properties of some Nigerian residual soils in relation with building problems. Engineering Geology 15:1-13.

28. Reyment, R.A.; (1965) Aspects of the Geology of Nigeria. University of Ibadan Press, Ibadan.

29. Wagner, A.A.; (1957) The use of the unified soil classification system by Bureau of Reclamation. Proc. $4^{\text {th }}$ Int. Conf. on Soil Mechanics and Foundation Engineering, London, 1:125.

30. Yao, Y.; Sun, H.; (2012) A novel silica aluminabased backfill material composed of coal refuse and fly ash. Journal of Hazards 213:71-82. 